\begin{tabular}{c|c|c}
\hline \hline Vol. 219: 41-49, 2001 & MARINE ECOLOGY PROGRESS SERIES \\
Mar Ecol Prog Ser & Published September 10 \\
\hline
\end{tabular}

\title{
Spring bloom nutrient dynamics in the Oslofjord
}

\author{
Svein Kristiansen*, Tove Farbrot, Lars-Johan Naustvoll \\ Department of Biology, University of Oslo, PO Box 1069 Blindern, 0316 Oslo, Norway
}

\begin{abstract}
Primary production and uptake rates of ammonium, nitrate and silicic acid were measured during the 1996 spring bloom in the Oslofjord, southern Norway, using isotope methodology

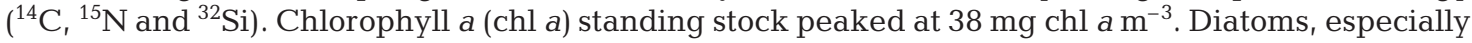
Thalassiosira nordenskioeldii, dominated the plankton community. The diatom bloom followed a sigmoid growth pattern until it abruptly declined. Both nitrate and silicic acid were depleted from the surface layer during the bloom. Nitrate was the major nitrogen-source for phytoplankton growth, the $f$-ratio was $>0.9$ until the bloom declined. Virtually all the silicic acid was converted into diatom frustules (biogenic silica), and silicon controlled the primary production during the bloom.
\end{abstract}

KEY WORDS: Diatoms $\cdot$ Thalassiosira nordenskioeldii $\cdot$ Spring $\cdot$ Silicic acid $\cdot$ Coagulation $\cdot$ Fjords

\section{INTRODUCTION}

The spring bloom is a characteristic feature of many northern temperate coastal ecosystems (Cebrián \& Valiela 1999). Autotrophic production and heterotrophic consumption are uncoupled during the spring bloom, and this uncoupling results in dense phytoplankton populations which may deplete most of the nutrients in the euphotic zone (Bienfang \& Ziemann 1992, Kudo et al. 2000). However, the spring bloom may also decline in nutrient-rich water because of unfavourable meteorological and hydrographical conditions (Levasseur et al. 1984, Cloern 1996).

Aggregation of cells followed by rapid mass sedimentation of larger aggregates have often been observed during algal blooms, especially during the latter parts of the blooms (Smetacek 1985, Kiørboe 1996). Lately, coagulation of cells (stickiness of colliding particles) into rapidly sinking aggregates has been suggested as an important factor in regulating the spring bloom in coastal waters which are not yet nutrientdepleted (Jackson 1990, Kiørboe 1996). It has also been

${ }^{*}$ Present address: Norwegian College of Fishery Science (NFH), University of Tromsø, Breivika, 9037 Tromsø, Norway. E-mail: sveinkr@nfh.uit.no shown experimentally in laboratory mesocosms that aggregation of cells may start prior to nutrient depletion (Alldredge et al. 1995).

Fjords offer ideal locations for studying the spring bloom. They are sheltered and the diatom spring bloom is usually an intense and rather short-lived event (Smayda 1980). In some Scandinavian fjords, phytoplankton spring blooms were shown to follow classical coagulation theory (Jackson 1990), and the nutrients were not depleted (Kiørboe et al. 1994, Tiselius \& Kuylenstierna 1996). In other fjords, the Oslofjord included, nutrients (nitrate or silicic acid) have been reported to become greatly reduced or depleted during the spring bloom (e.g. Lännergren \& Skjoldal 1976, Båmstedt 1985, Kristiansen 1987, Paasche \& Erga 1988). We studied the spring bloom in the Oslofjord in detail, and asked the following questions: Did nutrients limit the phytoplankton standing stock and production during the spring bloom? Why did the bloom collapse?

\section{MATERIALS AND METHODS}

Water samples were collected at $1 \mathrm{~m}$ depth from a pier in the Drøbaksund, a narrow neck of the Oslofjord, southern Norway $\left(59^{\circ} 40.0^{\prime} \mathrm{N}, 10^{\circ} 37.6^{\prime} \mathrm{E}\right.$; maximum water depth ca $80 \mathrm{~m}$ ). Heavy ice in the fjord pre- 
vented more detailed sampling (Table 1). Nine samples were collected from 27 February to 26 March 1996 using a non-toxic water sampling bottle (Vattenprovtager, 1500 ml, Aqua Produkter HB, Sweden).

Concentration of biogenic silica ( $\mathrm{BSi}$ ) was measured by soda hydrolysis (Paasche 1980). Particulate carbon (PC) and nitrogen (PN) were analyzed using a Carlo Erba Elemental Analyser and chlorophyll a (chl a) was measured in acetone extracts using a Turner Designs fluorometer calibrated against sigma chl $a$. The chl $a$ samples were filtered onto $0.6 \mu \mathrm{m}$ polycarbonate filters and analyzed immediately. The particulate samples were filtered onto $0.6 \mu \mathrm{m}$ polycarbonate filters (BSi) or precombusted GF/F filters (PC and PN), and the filters were dried at $60^{\circ} \mathrm{C}$ and analyzed 2 to 3 mo later. Phosphate and silicic acid concentrations were measured on frozen samples according to Strickland \& Parsons (1972), and ammonium concentration was measured less than $2 \mathrm{~h}$ after sampling according to Solórzano (1969). Nitrate and nitrite concentrations were measured on frozen samples using a ChemLab autoanalyzer and methods adapted from Strickland \& Parsons (1972). Quantitative plankton samples were preserved with neutralized formaldehyde and counted in an inverted microscope using $2 \mathrm{ml}$ (phytoplankton) or $50 \mathrm{ml}$ (microzooplankton) chambers. More than 150 cells were counted of the dominating phytoplankton species, and usually $<50$ cells were counted of the non-dominating species. Average cell dimensions were used to calculate phytoplankton carbon from cell volume by the equations given in Strathmann (1967). Some flagellates (both autotrophic cells and potentially important grazers) may have been lost during the fixation. Delicate autotrophic flagellates have been found to be of minor importance during the spring bloom (Throndsen 1976, 1979).

Table 1. Surface ice cover (in quarters), salinity, and maximum surface irradiance (PAR) in the Drøbaksund, southern Norway. -: no data

\begin{tabular}{|cccc|}
\hline $\begin{array}{l}\text { Date } \\
(1996)\end{array}$ & $\begin{array}{c}\text { Ice } \\
\text { conditions }\end{array}$ & Salinity & $\begin{array}{c}\text { Max. surface PAR } \\
\left(\mathrm{mol} \mathrm{m}^{-2} \mathrm{~h}^{-1}\right)\end{array}$ \\
\hline Feb & & - & \\
27 & $3 / 4$ & 25.78 & 1.9 \\
29 & $3 / 4$ & & 2.4 \\
Mar & & 26.12 & \\
5 & $1 / 2$ & 27.89 & 2.7 \\
8 & $1 / 2$ & 28.25 & 1.6 \\
12 & $1 / 2$ & 27.80 & 2.3 \\
15 & $3 / 4$ & 28.40 & 2.8 \\
19 & $3 / 4$ & 28.23 & 2.3 \\
22 & $1 / 4$ & 25.71 & 3.2 \\
26 & $\ll 1 / 4$ & & 3.2 \\
\hline
\end{tabular}

The heterotrophic dinoflagellate Gyrodinium spirale may graze on Thalassiosira nordenskioeldii (authors' own obs.). Abundances of this and similar delicate flagellates were probably underestimated in our samples. However, microscopic examination of live samples did not reveal large numbers of flagellates. Our estimates of dominating species should thus be reasonable.

Several methods are available for studying nutrient limitation of phytoplankton growth. However, most methods have shortcomings, and it is often difficult to identify nutrient limited phytoplankton growth in the sea (Harris 1986, Valiela 1995). We chose to combine nutrient concentrations and phytoplankton abundance with short-term physiological measurements (primary production and uptake rates of $\mathrm{N}$ and $\mathrm{Si}$ ). Primary production and uptake rates of ammonium, nitrate and silicic acid were measured using the isotopes ${ }^{14} \mathrm{C}$ (Strickland \& Parsons 1972), ${ }^{15} \mathrm{~N}$ (Kristiansen $\&$ Paasche 1989) and ${ }^{32} \mathrm{Si}$. The silicon uptake rates $\left({ }^{32} \mathrm{Si}\right)$ are from Kristiansen et al. (2000). The isotopes were added to separate polycarbonate incubation bottles, incubated for $5 \mathrm{~h}$ (10:00 to 15:00 h local time) at in situ temperature (between -1 and $0^{\circ} \mathrm{C}$ ) and exposed to $50 \%$ of surface irradiance. The incubations were terminated by filtering the samples onto GF/F glass microfibre filters $\left({ }^{15} \mathrm{~N}\right)$ or onto $0.6 \mu \mathrm{m}$ polycarbonate filters $\left({ }^{14} \mathrm{C}\right.$ and $\left.{ }^{32} \mathrm{Si}\right)$. The funnels and filters were finally rinsed with 5 to $10 \mathrm{ml}$ filtered seawater (0.6 $\mathrm{mm}$ polycarbonate), and all the filters were dried at $60^{\circ} \mathrm{C}$. Activities of the isotopes were $220 \mathrm{kBq}{ }^{14} \mathrm{C}$ and $0.7 \mathrm{kBq}{ }^{32} \mathrm{Si}$ added to $250 \mathrm{ml}$ samples, and $0.05 \mu \mathrm{mol}$ ammonium, $0.05 \mu \mathrm{mol}$ and $0.5 \mu \mathrm{mol}$ nitrate (all 99 at. $\%{ }^{15} \mathrm{~N}$ ) added to $1000 \mathrm{ml}$ samples. Ambient nitrate concentrations on 22 and 26 March were $\leq 0.2 \mathrm{mmol} \mathrm{m} \mathrm{m}^{-3}$. The corresponding nitrate uptake rates are from the low ${ }^{15} \mathrm{~N}(0.05 \mu \mathrm{mol})$-addition bottles, the other nitrate uptake rates (ambient nitrate concentrations $>4 \mathrm{mmol} \mathrm{m}^{-3}$ ) are from the high ${ }^{15} \mathrm{~N}$ $(0.5 \mu \mathrm{mol})$-addition bottles.

Coagulation theory (Jackson 1990) was used to calculate critical cell concentrations (net algal growth balanced by coagulation and grazing) of the dominating species. The stickiness coefficient was an averaged literature value $(0.15)$, the fluid shear rate was calculated from the wind speed, and the cell size was single-cell equivalent spherical diameter calculated from size measurements of the individual species (see Tiselius \& Kuylenstierna 1996). Net algal growth rates $\left(\mathrm{d}^{-1}\right)$ were calculated by regression of the natural logarithm of the cell concentrations from the 3 first samplings versus time. Salinity was measured using a salinometer (YEO-KAL model 601Mk1V). Irradiance (PAR) was measured using LI-COR quantum sensors. 


\section{RESULTS}

A variable breeze prevailed in the fjord during the spring bloom, with a daily average wind speed of $<5 \mathrm{~m} \mathrm{~s}^{-1}$ (Fig. 1). Two periods of very weak winds $\left(<2 \mathrm{~m} \mathrm{~s}^{-1}\right.$ on 2 to 11 and 17 to $\left.24 \mathrm{March}\right)$ were interrupted by days with slightly stronger winds (3 to $5 \mathrm{~m} \mathrm{~s}^{-1}$ ). Surface irradiance (PAR) also varied (Fig. 1). Generally it increased (almost doubled) during the sampling period, and the daily maximum surface irradiance was in the range 1.6 to $3.2 \mathrm{~mol} \mathrm{~m}^{-2} \mathrm{~h}^{-1}$ on the sampling dates (Table 1). The fjord was partly filled by broken ice until our last sampling date (Table 1), and our sampling regime had to be restricted to $1 \mathrm{~m}$ depth at 1 station only. The surface layer (upper $5 \mathrm{~m}$ ) was well mixed and the main pycnocline was situated at 20 to $25 \mathrm{~m}$ depth (Fig. 2). Our sampling started during the early phase of the spring bloom $\left(4.9 \mathrm{mg} \mathrm{chl} \mathrm{a} \mathrm{m}^{-3}\right.$ : Table 2). Concentrations of nitrate, phosphate and silicic acid gradually decreased during the bloom. The surface water became silicic acid-depleted first
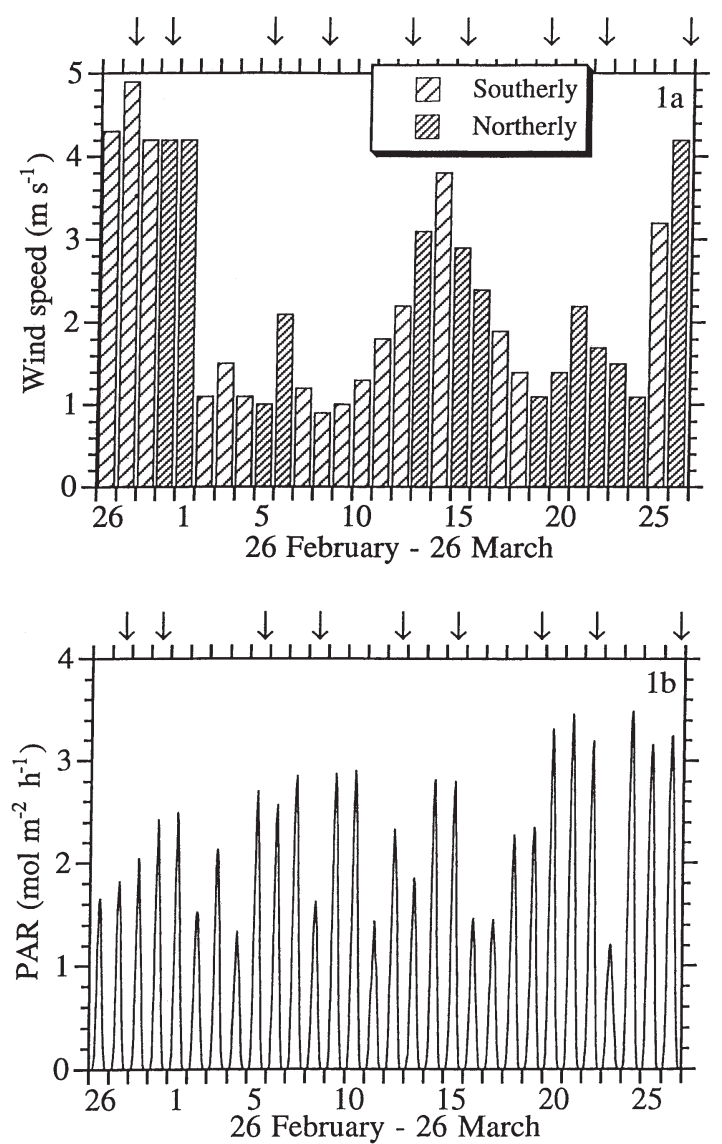

Fig. 1. (a) Average daily wind speed; (b) hourly surface irradiance in Drøbaksund, February and March 1996. The fjord is oriented north-south, and dominating northerly or southerly winds are shown. Sampling dates are indicated by arrows.

(Data from Department of Agricultural Engineering, Ås)

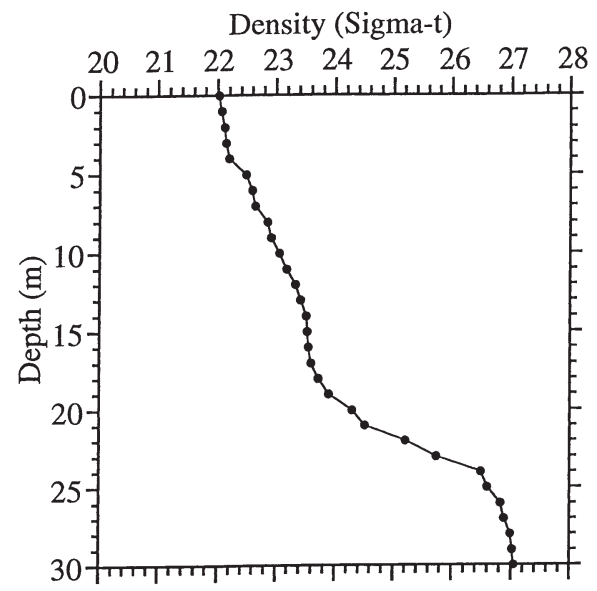

Fig. 2. Seawater density (sigma-t) at a station $2 \mathrm{~km}$ south of sampling site on 22 March 1996. (Data from J. Magnusson [NIVA])

(19 March). Three days later the surface water was also nitrate-depleted, and the bloom collapsed. All available silicic acid was converted into BSi during the bloom. BSi accounted for 17 and $99 \%$ of the silicon $\left(\mathrm{BSi}+\mathrm{Si}[\mathrm{OH}]_{4}\right)$ in our first sample and when the bloom declined, respectively. One sample was collected after the bloom collapsed (26 March). The nitrate and silicic acid concentrations increased slightly in this last sample, while the phosphate concentration decreased further. The concentration of chl a was $\geq 23 \mathrm{mg} \mathrm{m}^{-3}$ for almost 3 wk ( 5 to 22 March), and the bloom peaked on 19 March (38 $\mathrm{mg} \mathrm{chl} \mathrm{a} \mathrm{m}^{-3}$ ).

Diatoms dominated the plankton community (Fig. 3), and a total of 25 diatoms and 16 autotrophic flagellates (dinoflagellates, euglenophytes and prymnesiophytes) were identified in the samples. The most abundant species were the diatoms Thalassiosira nordenskioeldii Cleve and Chaetoceros socialis Lauder, with similar maximum cell concentrations $\left(1.4\right.$ and $1.2 \times 10^{9}$ cells m$^{-3}$,

Table 2. Nitrate, phosphate, silicic acid and biogenic silica (BSi) (all $\left.\mathrm{mmol} \mathrm{m}^{-3}\right)$, and chlorophyll $a\left(\mathrm{mg} \mathrm{m}^{-3}\right)$ concentrations in Drøbaksund

\begin{tabular}{|lrcccr|}
\hline Date (1996) & Nitrate & Phosphate & Silicic acid & BSi & Chl $a$ \\
\hline Feb & & & & & \\
27 & 8.1 & 0.43 & 7.6 & 1.5 & 4.9 \\
29 & 5.4 & 0.23 & 6.3 & 3.2 & 12.2 \\
Mar & & & & & \\
5 & 3.8 & 0.11 & 4.6 & 6.0 & 22.7 \\
8 & 5.7 & 0.22 & 3.6 & 7.9 & 27.3 \\
12 & 6.0 & 0.20 & 3.5 & 8.6 & 27.2 \\
15 & 6.7 & 0.18 & 2.6 & 9.7 & 32.3 \\
19 & 5.5 & 0.15 & 0.5 & 9.8 & 37.5 \\
22 & $<0.2$ & 0.13 & 0.05 & 9.4 & 23.9 \\
26 & 0.2 & 0.06 & 0.4 & 4.4 & 4.1 \\
\hline
\end{tabular}




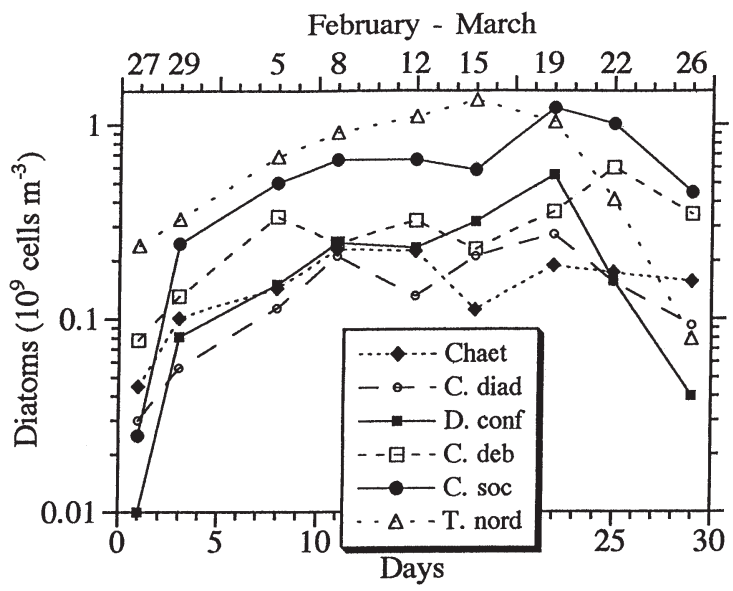

Fig. 3. Cell concentrations of 6 dominating phytoplankton species during study period. Only species with abundances of $\geq 50$ cells ml $\mathrm{ml}^{-1}$ in 1 or more of the samples are included. C. diad: Chaetoceros diadema (Ehrenberg) Gran; C. deb: C. debilis Cleve; C. soc: C. socialis Lauder; Chaet: Chaetoceros sp.; D. conf: Detonula confervacea (Cleve) Gran; T. nord: Thalassiosira nordenskioeldii Cleve

respectively). Converted to phytoplankton $\mathrm{C}$ biomass $\left(\mathrm{C}_{\text {phyto }}\right)$, the diatoms accounted for 94 to $99 \%$ of $\mathrm{C}_{\text {phyto }}$ with $T$. nordenskioeldii alone accounting for 66 to $74 \%$ until 22 March (Fig. 4). The other abundant diatom, C. socialis, is small and accounted for $<7 \%$ of $\mathrm{C}_{\text {phyto }}$. Only a few heterotrophs were observed in our samples (dinoflagellates, ciliates, tintinnids and copepods). However, microzooplankton abundance was twice as high when the bloom collapsed (Fig. 5).

During the most intense part of the bloom (23 to $38 \mathrm{mg} \mathrm{chl} \mathrm{a} \mathrm{m}{ }^{-3}: 5$ to 19 March) the particulate ratios were stable (Table 3 ). The ratios between chl $a$ and particulate $\mathrm{C}(\mathrm{chl} a: \mathrm{C})$, between phytoplankton $\mathrm{C}$ biomass and particulate $\mathrm{C}\left(\mathrm{C}_{\text {phyto }}: \mathrm{C}\right)$, between particulate

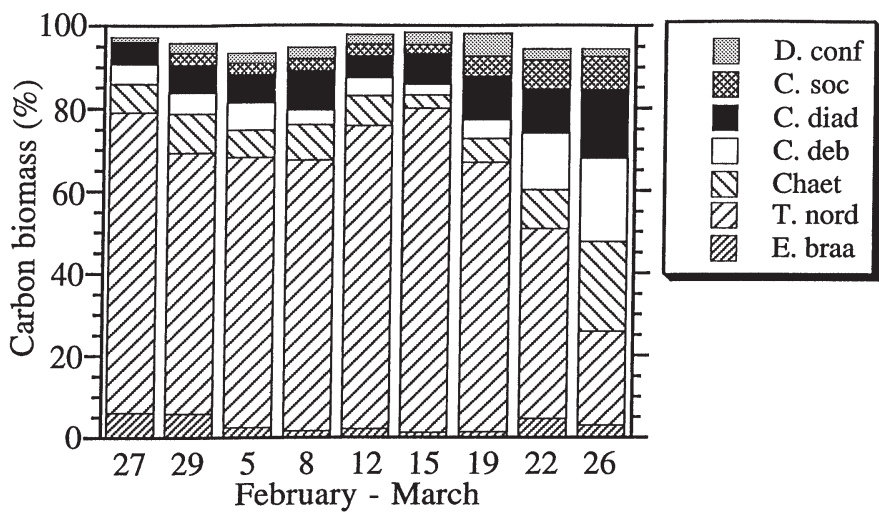

Fig. 4. Dominating species during study period (as percentage of phytoplankton carbon). Only species accounting for $>5 \%$ of phytoplankton $\mathrm{C}$ in 1 or more of the samples are included. E. braa: Eutreptiella cf. braarudii; other abbreviations as in legend to Fig. 3

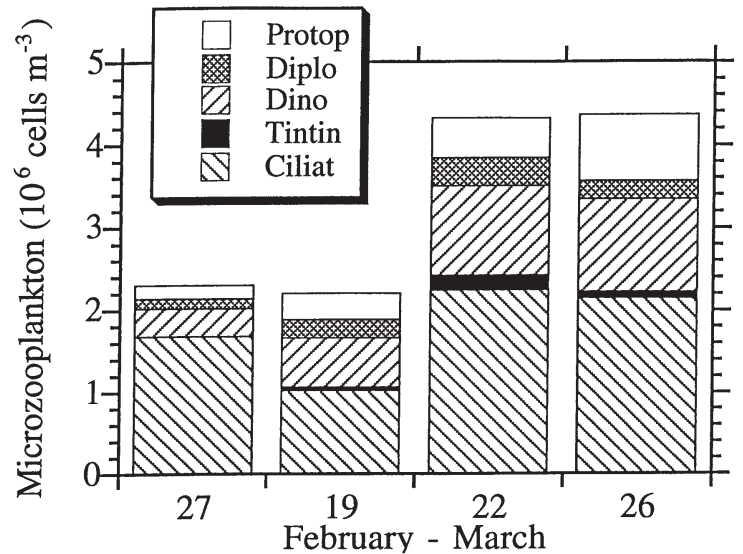

Fig. 5. Dominating groups of microzooplankton during study period. Ciliat: oligotrich ciliates; Diplo: Diplopsalis-group; Dino: unarmoured dinoflagellates; Tintin: tintinnids; Protop: Protoperidinium spp.

$\mathrm{N}$ and $\mathrm{C}(\mathrm{N}: \mathrm{C})$ and between particulate $\mathrm{N}$ and $\mathrm{Si}(\mathrm{N}: \mathrm{Si})$ all decreased when the bloom collapsed (about 70, 50, 30 and $30 \%$ decrease, respectively). The decreasing ratios indicate an increasing detritus fraction when the bloom collapsed, and the microscopic examination of the samples revealed increasing numbers of empty diatom frustules on the last sampling dates.

Primary production and the absolute uptake rates of ammonium plus nitrate (AN) and of Si all increased gradually during the first part of the bloom (Fig. 6). After 15 March the rates decreased abruptly, before maxima in chl $a$ and total cell abundance were reached (Fig. 3, Table 2). The chl a-specific rates were high until 15 March (primary production and $\mathrm{Si}$ ) or 19 March (AN) and then decreased (Table 4). The $f$-ratio (nitrate uptake rate divided by summed ammonium plus nitrate uptake rates) was $\geq 0.88$ until 19 March and then decreased to 0.48 on 22 March. The weak

Table 3. Ratios between chlorophyll $a$ and particulate $\mathrm{C}$ (Chl a: $\mathrm{C}$ in $\mathrm{g} \mathrm{mol}^{-1}$ ), between phytoplankton $\mathrm{C}$ and particulate $\mathrm{C}\left(\mathrm{C}_{\text {phyto }}: \mathrm{C}\right)$, between particulate $\mathrm{N}$ and $\mathrm{C}$, and between particulate $\mathrm{N}$ and biogenic $\mathrm{Si}$ (N:Si) (all atomic ratios) in Drøbaksund

\begin{tabular}{|lcccc|}
\hline Date (1996) & Chl a:C & $\mathrm{C}_{\text {phyto }}: \mathrm{C}$ & $\mathrm{N}: \mathrm{C}$ & $\mathrm{N}: \mathrm{Si}$ \\
\hline Feb & & & & \\
29 & 0.46 & 0.7 & 0.11 & 0.88 \\
& & & & \\
Mar & & & & \\
5 & 0.62 & 1.0 & 0.12 & 0.71 \\
8 & 0.70 & 1.3 & 0.11 & 0.56 \\
12 & 0.60 & 1.2 & 0.11 & 0.59 \\
15 & 0.62 & 1.2 & 0.12 & 0.63 \\
19 & 0.63 & 1.0 & 0.12 & 0.73 \\
22 & 0.44 & 0.6 & 0.09 & 0.52 \\
26 & 0.17 & 0.5 & 0.08 & 0.44 \\
\hline
\end{tabular}




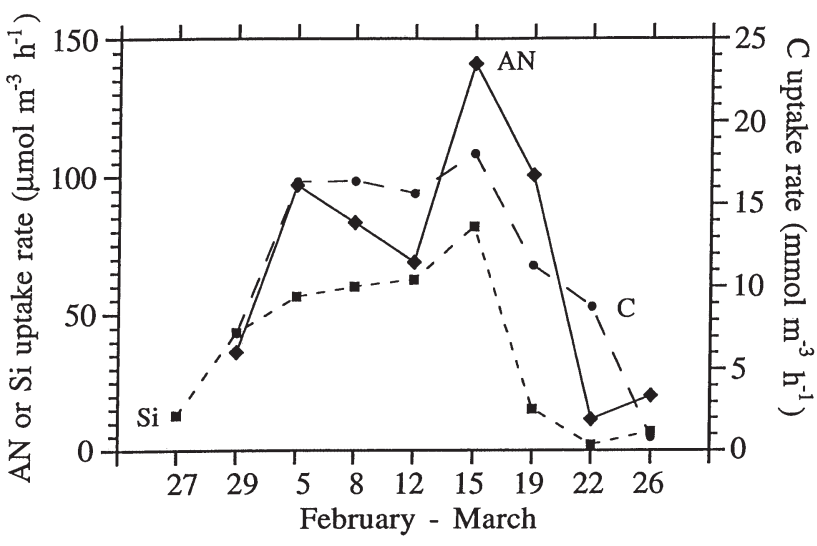

Fig. 6. Primary production (C) and ammonium + nitrate (AN) and $\mathrm{Si}$ uptake rates during study period

Table 4. Chlorophyll a-specific primary production in $\mu$ mol C $(\mu \mathrm{g} \text { chl } a)^{-1} \mathrm{~h}^{-1}$, chlorophyll a-specific AN (ammonium + nitrate) uptake rate in nmol N ( $\mu \mathrm{g} \mathrm{chl} a)^{-1} \mathrm{~h}^{-1}$ and Si uptake rate in nmol Si $(\mu \mathrm{g} \mathrm{chl} a)^{-1} \mathrm{~h}^{-1}$, and $f$-ratio in Drøbaksund. -: no data

\begin{tabular}{|ccccc|}
\hline \multirow{2}{*}{$\begin{array}{l}\text { Date } \\
(1996)\end{array}$} & \multicolumn{4}{c}{ Chlorophyll $a$-specific rates } \\
Prim. prod. & AN-rate & Si-rate & \\
\hline Feb & & & & \\
27 & - & - & 2.7 & - \\
29 & 0.59 & 7.4 & 3.6 & 0.88 \\
Mar & & & & \\
5 & 0.72 & 7.9 & 2.5 & 0.94 \\
8 & 0.60 & 3.7 & 2.2 & 0.89 \\
12 & 0.57 & 2.5 & 2.3 & 0.92 \\
15 & 0.56 & 5.2 & 2.5 & 0.96 \\
19 & 0.30 & 3.1 & 0.4 & 0.95 \\
22 & 0.37 & 0.3 & 0.1 & 0.48 \\
26 & 0.20 & 0.9 & 1.7 & 0.67 \\
\hline
\end{tabular}

increase in nitrate and silicic acid concentrations from 22 to 26 March was followed by increases also in the $f$-ratio and in the AN and Si uptake rates. Ammonium concentration was $0.8 \mathrm{mmol} \mathrm{m}^{-3}$ in our first sample (27 February). It decreased to $<0.2 \mathrm{mmol} \mathrm{m}^{-3}$ in the subsequent samples and did not increase when the bloom declined. Significant correlations were found between chl $a$-specific primary production and the silicic acid concentration $(F=15.3, \mathrm{p}<0.008)$, between chl $a$-specific nitrate uptake rate and the silicic acid concentration $(F=11.9, \mathrm{p}<0.02)$ and between chl $a-$ specific silicic acid uptake rate and the silicic acid concentration $(F=23.1, \mathrm{p}<0.003)$. No significant correlations were found between the same chl a-specific rates and the nitrate concentration ( $p>0.1$ for all).

The cell concentrations of the 6 most abundant species declined on different dates (Fig. 3). Cell concentrations of Thalassiosira nordenskioeldii declined after 15 March, Chaetoceros socialis, C. diadema (Ehrenberg) Gran and Detonula confervacea (Cleve) Gran after 19 March, and C. debilis Cleve after 22 March. $T$. nordenskioeldii and $D$. confervacea both declined by $20 \% \mathrm{~d}^{-1}$, while $C$. debilis, C. socialis and C. diadema declined by 10 to $15 \% \mathrm{~d}^{-1}$. The cell concentration of Chaetoceros sp. was low and variable, and declined by $3 \% \mathrm{~d}^{-1}$. The maximum observed cell concentration for the dominating diatoms and the corresponding calculated critical cell concentrations using coagulation theory are compared in Table 5. The critical concentrations are approximate values only. This is mainly because we used a constant stickiness coefficient $(\alpha)$ in the calculations and because the critical cell concentrations were calculated for individual species. The $\alpha$ is known to be variable (Kiørboe 1993, Kiørboe et al. 1994). Species may also coagulate with each other, and sticky species may cause non-sticky ones to coagulate (Hansen et al. 1995, Hansen \& Kiørboe 1997). T. nordenskioeldii is a sticky diatom (Hansen \& Kiørboe 1997), and it dominated the phytoplankton community in the fjord until 15 March because of its high cell concentration and large cell size (Figs 3 \& 4). It should therefore be legitimate to treat the coagulation of $T$. nordenskioeldii separately. The equation for critical concentration requires that the net growth rate is constant over time. Net growth rate of $T$. nordenskioeldii calculated from the first 3 samplings was constant (0.15 $\mathrm{d}^{-1}$ from 27 February to 5 March: Table 5). Moreover, the chl a-specific primary production indi-

Table 5. Equivalent spherical diameter (ESD), daily average shear rate the last $2 \mathrm{~d}$ before maximum cell concentration of the dominant phytoplankton species, net growth rate \pm SE for the first 3 samplings, calculated critical cell concentration, and maximum cell concentration recorded during study period

\begin{tabular}{|lcccr|}
\hline Species & $\begin{array}{c}\text { ESD } \\
(\mu \mathrm{m})\end{array}$ & $\begin{array}{c}\text { Shear rate } \\
\left(\mathrm{s}^{-1}\right)\end{array}$ & $\begin{array}{c}\text { Net growth rate } \\
\left(\mathrm{d}^{-1}\right)\end{array}$ & $\begin{array}{c}\text { Cell conc. }\left(10^{9} \mathrm{~m}^{-3}\right) \\
\text { Max. } \\
\text { Critical }\end{array}$ \\
\hline Thalassiosira nordenskioeldii & 27.9 & 0.24 & $0.15 \pm 0.02$ & 1.0 \\
Detonula confervacea & 12.1 & 0.08 & $0.34 \pm 0.21$ & 76 \\
Chaetoceros debilis & 13.7 & 0.09 & $0.20 \pm 0.02$ & 28 \\
Chaetoceros diadema & 22.5 & 0.08 & $0.18 \pm 0.04$ & 6.4 \\
Chaetoceros socialis & 8.2 & 0.08 & $0.37 \pm 0.22$ & 0.60 \\
Chaetoceros sp. & 15.9 & 0.07 & $0.15 \pm 0.07$ & 0.27 \\
& & & & 0.22 \\
\hline
\end{tabular}


cates that the growth rate of $T$. nordenskioeldii, the dominating diatom, was fairly constant at least until 15 March (Table 4). The maximum observed cell concentration of $T$. nordenskioeldii $\left(1.35 \times 10^{9} \mathrm{~m}^{-3}\right)$ was close to its calculated critical cell concentration $(1.0 \times$ $10^{9} \mathrm{~m}^{-3}$ : Table 5). Maximum cell concentrations of the other 5 dominating diatoms were $<5 \%$ of the corresponding calculated critical cell concentrations.

Phytoplankton standing stock decreased in our samples (1 m depth) after 19 March (Table 2, Fig. 3). The surface layer (0 to $5 \mathrm{~m}$ ) was well mixed when the bloom declined (Fig. 2). By assuming a $5 \mathrm{~m}$ homogeneous upper layer, hypothetical sedimentation rates (no other loss-terms) can be estimated from the measured concentrations of PC. These hypothetical sedimentation rates were $92 \mathrm{mg} \mathrm{C} \mathrm{m}^{-2} \mathrm{~d}^{-1}$ during the period 19 to 22 March and $470 \mathrm{mg} \mathrm{C} \mathrm{m}^{-2} \mathrm{~d}^{-1}$ during the period 22 to 26 March.

\section{DISCUSSION}

The diatom Thalassiosira nordenskioeldii dominated most of the spring bloom. Its cell concentration decreased during the last week of the period, and a mixture of 6 diatoms (T. nordenskioeldii, Detonula confervacea, Chaetoceros sp., C. debilis, C. socialis, C. diadema) then dominated the phytoplankton community. These 6 diatoms are all common spring forms in the fjord, and T. nordenskioeldii often dominates during early spring (Hasle \& Smayda 1960, Lange et al. 1992). Nutrients often become exhausted during the diatom spring bloom in coastal areas (Pratt 1965, Valiela 1995). In Scandinavian waters, several studies have shown that nitrate, silicic acid and phosphate (1 or several of them) become exhausted during the spring bloom (e.g. Lännergren \& Skjoldal 1976, Sahlsten et al. 1988, Lignell et al. 1992, Kuosa et al. 1997). Silicic acid is of special interest because silicic acid depletion seems to alter the phytoplankton community from diatom-dominated to flagellate-dominated (Officer \& Ryther 1980, Malone et al. 1996). Both nitrate and silicic acid may be exhausted during the spring bloom in the Oslofjord (Paasche \& Østergren 1980, Kristiansen 1987). However, low nutrient concentrations do not necessarily imply low phytoplankton growth rates (Goldman et al. 1979, McCarthy \& Goldman 1979). Paasche \& Erga (1988) used several criteria to identify potential nitrogen or phosphorus limitation of phytoplankton growth in the Oslofjord, and they concluded that the spring bloom was limited by nitrogen. We studied nutrient dynamics at $1 \mathrm{~m}$ depth during the spring bloom in detail.

Variables measured during the bloom are listed in Table 6. Based on the discussion below, conditions for net phytoplankton growth during the bloom are summarized in the same table. The growth conditions are tentatively classified into 3 groups of net phytoplankton growth (no reduction in growth, weak reduction and strong reduction). Variables that may have caused the collapse of the bloom are also identified in Table 6 . Increased surface irradiance probably triggers the spring bloom in the fjord (Smayda 1959). A vertical attenuation coefficient for downward irradiance (PAR) of $0.4 \mathrm{~m}^{-1}$ was measured at a nearby ice-free station on 22 March (data from J. Magnusson, Norwegian Institute of Water Research, Oslo). Using this attenuation coefficient $\left(0.4 \mathrm{~m}^{-1}\right)$, estimated irradiance at $5 \mathrm{~m}$ depth was $<0.39 \mathrm{~mol} \mathrm{~m}^{-2} \mathrm{~h}^{-1}$ when the bloom collapsed on 19 to 26 March. Phytoplankton growth rate in the upper mixed layer ( 0 to $5 \mathrm{~m}$ ) may therefore have been lightlimited. However, surface irradiance increased during the sampling period and the ice cover was greatly reduced after 19 March (Fig. 1b, Table 1). It is therefore unlikely that the bloom declined because of low irradiance. The concentrations of nitrate and silicic

Table 6. Selected variables measured during the 1996 spring bloom, showing suboptimal conditions for net phytoplankton growth. -: No reduction in growth; $\mathrm{x}$ : weak reduction; xx: strong reduction. Variables that may have caused the collapse of the bloom are given in last column. AN: ammonium + nitrate

\begin{tabular}{|c|c|c|c|c|c|c|}
\hline Variable & 27 Feb - 5 Mar & 8 - 15 Mar & 19 Mar & 22 Mar & 26 Mar & Caused collapse \\
\hline Chlorophyll a (\%) & $13-61$ & $73-86$ & 100 & 64 & 11 & - \\
\hline $\mathrm{NO}_{3}$ concentration & - & - & - & $\mathrm{xx}$ & $\mathrm{xx}$ & $\mathrm{NO}_{3}$ \\
\hline $\mathrm{Si}(\mathrm{OH})_{4}$ concentration & - & - & $\mathrm{xx}$ & $\mathrm{xx}$ & $\mathrm{xx}$ & $\mathrm{Si}(\mathrm{OH})_{4}$ \\
\hline $\mathrm{PO}_{4}$ concentration & - & - & - & - & $\mathrm{xx}$ & - \\
\hline Primary production/chlorophyll a & - & - & $\mathrm{xx}$ & $\mathrm{xx}$ & $\mathrm{xx}$ & - \\
\hline $\mathrm{Si} /$ chlorophyll a uptake rate & - & - & $\mathrm{xx}$ & $\mathrm{xx}$ & $\mathrm{xx}$ & $\mathrm{Si}(\mathrm{OH})_{4}$ \\
\hline AN/chlorophyll a uptake rate & - & $\mathrm{x}$ & $\mathrm{x}$ & $\mathrm{x}$ & $\mathrm{xx}$ & $\mathrm{NO}_{3}$ \\
\hline$f$-ratio & - & - & - & $\mathrm{xx}$ & $\mathrm{xx}$ & - \\
\hline Grazing & - & - & - & - & - & - \\
\hline Critical conc. of Thalassiosira norden. & - & $\mathrm{x}$ & $\mathrm{x}$ & $\mathrm{x}$ & - & - \\
\hline Critical conc. of other species & - & - & - & - & - & - \\
\hline
\end{tabular}


acid were close to the detection limit when the bloom declined (after 19 March: Table 2). Silicic acid was depleted before nitrate, and the bloom collapsed when the nitrate was depleted. The bloom therefore collapsed because of nutrient deficiency (Table 6). Virtually all dissolved silicic acid was converted into BSi during the bloom (Table 2), and most of it (79\%) was incorporated into the frustules of Thalassiosira nordenskioeldii (Kristiansen et al. 2000). This converts into 11 pmol BSi cell ${ }^{-1}$, which is a reasonable cell quota for this species at low temperatures (Durbin 1977). Similar high cell concentrations of $T$. nordenskioeldii (1.2 to $1.3 \times 10^{9}$ cells m${ }^{-3}$ ) were found in 1957, 1958 and 1974 (Hasle \& Smayda 1960, Hasle pers. comm.), and we are not aware of any higher cell concentration of $T$. nordenskioeldii reported from the fjord. The high abundance is probably close to the upper limit of T. nordenskioeldii during the spring bloom in the fjord. The particulate ratios (Table 3 ) varied through the bloom. Most of them indicate changing growth conditions when the bloom collapsed (after 19 March). Primary production and chl a-specific primary production both decreased after 15 March (Fig. 6, Table 4). Consequently, the phytoplankton growth rate also decreased after 15 March. The absolute and chl a-specific Si uptake rates decreased after $15 \mathrm{March}$, as did the primary production, while the corresponding AN uptake rates decreased after 19 March. The relative uptake rates of ammonium and nitrate ( $f$-ratios) must be used with great caution for estimating new and regenerated production in inshore waters. There was no evidence, however, of significant effects of land-originated nutrients on the $f$-ratios reported here. The $f$-ratios indicated a shift from an almost totally new-productiondominated system using nitrate as $\mathrm{N}$ source for growth $(f$-ratio $>0.9)$ to a more regenerative system using equal amounts of nitrate and ammonium as nitrogen sources $(f$-ratio $=0.5$ to 0.7 ) after 19 March. The decline in the $f$-ratio fits well with phytoplankton standing stock, which also decreased after 19 March.

The concentrations of nitrate and silicic acid became depleted during the bloom, and the uptake rates of the same nutrients clearly showed that the phytoplankton growth rate became nutrient-limited towards the end of the bloom (Table 6). Furthermore, positive relationships were found between chl a-specific primary production and the silicic acid concentration and between chl a-specific nitrate uptake rate and the silicic acid concentration. No significant relationships were found between the same rates and the nitrate concentration. Thus, silicic acid probably controlled the phytoplankton growth rate during the bloom, and the bloom collapsed because of silicic acid depletion.

The net growth rate (rate of biomass accumulation) declined after about 5 March while the biomass de- clined 2 wk later (Table 2, Fig. 3). It also declined well before the phytoplankton community growth rate, the chl a-specific nutrient uptake rates and the $f$-ratio, which all decreased after 15 March (Table 4). Grazing, lateral advection and sedimentation may have reduced phytoplankton standing stock in the surface layer. Grazing pressure is usually considered to be low during the spring bloom in northern coastal waters, and the bulk of the spring bloom often sediments out of the water column (Smetacek 1980, Wassmann 1991). The abundances of potential microzooplankton grazers in the fjord were low (Fig. 5). Larger zooplankton in the fjord (mainly copepods) usually over-winter in deep water. However, both day and night abundances of zooplankton were unusually low in March 1996 (E. Bagøien pers. comm.). Grazing pressure was therefore insignificant during the bloom. Lateral advection probably caused some of the temporal variability seen in the data, which was most pronounced in the concentrations of nitrate and phosphate on 5 to 8 March (Table 2). Unfortunately, severe ice conditions in the fjord greatly restricted our sampling regime, and we do not have any data on lateral advection. Generally, lateral advection in the fjord is tide- and wind-driven. The average tidal range in the fjord is very low $(<0.3 \mathrm{~m}$ : Ulshagen et al. 1995), and a variable breeze prevailed during the bloom (Fig. 1). The wind increased slightly towards the end of the period (25 to 26 March), but the bloom started to decline earlier (after 19 March: Fig 3, Table 2). Days with slightly increased wind speed also occurred twice during earlier phases of the bloom. Apparently, these tide and wind incidents did not have any profound effects on the development of the bloom. The whole data set, however, shows an exponentially growing spring bloom which gradually depleted the nutrient pools. We therefore believe that lateral advection did not greatly influence the interpretation of our data. The sigmoid growth until 15 March (Fig. 3) is consistent with classical coagulation theory which has been successfully used to explain the decline of spring blooms in Scandinavian waters (Kiørboe et al. 1994, Hansen et al. 1995, Tiselius \& Kuylenstierna 1996). Thalassiosira nordenskioeldii was the overall dominating phytoplankton species during the bloom (Fig. 4). The critical concentration of this diatom was estimated from the available data and a reasonable stickiness coefficient obtained from the literature (see above), and this dominating diatom approached its estimated critical cell concentration after 5 March (Table 5, Fig. 3). Coagulation and sedimentation were not measured during the investigation. It is, however, reasonable that coagulation and sedimentation reduced the net growth rate for $2 \mathrm{wk}$ from 5 March until the bloom collapsed after 19 March.

When the bloom collapsed, the cell concentrations of the dominating species decreased by 10 to $20 \% \mathrm{~d}^{-1}$. 
The surface layer ( 0 to $5 \mathrm{~m}$ ) was well mixed when the bloom declined (Fig. 2). The hypothetical sedimentation rates calculated from the decline in the $\mathrm{PC}$ concentrations (90 to $470 \mathrm{mg} \mathrm{C} \mathrm{m}^{-2} \mathrm{~d}^{-1}$ ) are similar to the sedimentation rates measured during the spring bloom in Norwegian fjords and in the Kattegat (Skjoldal \& Wassmann 1986, Wassmann 1991, Olesen 1993). The spring bloom may therefore have sedimented out of the surface layer. Flocculation of diatoms into large and rapidly sinking aggregates is considered important for vertical transport of phytoplankton in the ocean, especially during the termination of blooms (Smetacek 1985, Kiørboe 1993). Such aggregates have also been observed during diatom blooms (Alldredge \& Gotschalk 1989, Olesen 1993, Tiselius \& Kuylenstierna 1996). Aggregation may occur through various mechanisms (Alldredge \& Jackson 1995). Mass sedimentation during our investigation was apparently triggered by nutrient depletion. The most relevant mechanism here is therefore changes in cell stickiness with changing physiological status of the cells, i.e. stickiness increase in nutrient-depleted cells (Hoagland et al. 1993, Kiørboe \& Hansen 1993).

In conclusion, the spring bloom was dominated by the diatom Thalassiosira nordenskioeldii. All available silicic acid and nitrate were depleted during the bloom, and all the silicic acid was converted into phytoplankton biomass. Silicic acid controlled the phytoplankton growth rate during the bloom. It is hypothesised that the net growth rate decreased because of coagulation and sedimentation during the most intense part of the bloom (5 to 19 March). The bloom collapsed because of nutrient depletion, probably silicic acid depletion, after 19 March.

Acknowledgements. Professor S. Myklestad (University of Trondheim) kindly analyzed the CN-samples. J. Magnusson (Norwegian Institute of Water Research, Oslo) and Professor G. R. Hasle (University of Oslo) made unpublished data from the Oslofjord available to us. Meteorological measurements were obtained from Department of Agricultural Engineering, Ås. This work was funded by the Research Council of Norway.

\section{LITERATURE CITED}

Alldredge AL, Gotschalk CC (1989) Direct observations of the mass flocculation of diatom blooms: characteristics, settling velocities and formation of diatom aggregates. Deep-Sea Res 36:159-171

Alldredge AL, Jackson GA (1995) Preface: aggregation in marine systems. Deep-Sea Res Part II Top Stud Oceanogr 42:1-7

Alldredge AL, Gotschalk C, Passow U, Riebesell U (1995) Mass aggregation of diatom blooms: insights from a mesocosm study. Deep-Sea Res Part II Top Stud Oceanogr 42:9-27

Båmstedt U (1985) Spring-bloom dynamics in Kosterfjorden, western Sweden: variation in phytoplankton production and macrozooplankton characteristics. Sarsia 70:69-82

Bienfang PK, Ziemann DA (1992) The role of coastal high latitude ecosystems in global export production. In: Falkowski PG, Woodhead AD (eds) Primary productivity and biogeochemical cycles in the sea. Plenum Press, New York, p 285-297

Cebrián J, Valiela I (1999) Seasonal patterns in phytoplankton biomass in coastal ecosystems. J Plankton Res 21:429-444

Cloern JE (1996) Phytoplankton bloom dynamics in coastal ecosystems: a review with some general lessons from sustained investigations of San Francisco Bay, California. Rev Geophys 34:127-168

Durbin EG (1977) Studies on the autecology of the marine diatom Thalassiosira nordenskioeldii. II. The influence of cell size on growth rate, and carbon, nitrogen, chlorophyll a and silica content. J Phycol 13:150-155

Goldman JC, McCarthy JJ, Peavey DG (1979) Growth rate influence on the chemical composition of phytoplankton in oceanic waters. Nature 279:210-215

Hansen JLS, Kiørboe T (1997) Quantifying interspecific coagulation efficiency of phytoplankton. Mar Ecol Prog Ser 159:75-79

Hansen JLS, Timm U, Kiørboe T (1995) Adaptive significance of phytoplankton stickiness with emphasis on the diatom Skeletonema costatum. Mar Biol 123:667-676

Harris GP (1986) Phytoplankton ecology: structure, function and fluctuation. Chapman \& Hall, London

Hasle GR, Smayda TJ (1960) The annual phytoplankton cycle at Drøbak, Oslofjord. Nytt Mag Bot (Oslo) 8:53-75

Hoagland KD, Rosowski JR, Gretz MR, Roemer SC (1993) Diatom extracellular polymeric substances: function, fine structure, chemistry, and physiology. J Phycol 29:537-566

Jackson GA (1990) A model of the formation of marine algal flocs by physical coagulation processes. Deep-Sea Res 37: $1197-1211$

Kiørboe T (1993) Turbulence, phytoplankton cell size, and the structure of pelagic food webs. Adv Mar Biol 29:1-72

Kiørboe T (1996) Material flux in the water column. In: Jørgensen BB, Richardson K (eds) Eutrophication in coastal marine ecosystems. American Geophysical Union, Washington, DC, p 67-94

Kiørboe T, Hansen JLS (1993) Phytoplankton aggregate formation: observations of patterns and mechanisms of cell sticking and the significance of exopolymeric material. J Plankton Res 15:993-1018

Kiørboe T, Lundsgaard C, Olesen M, Hansen JLS (1994) Aggregation and sedimentation processes during a spring phytoplankton bloom: a field experiment to test coagulation theory. J Mar Res 52:297-323

Kristiansen S (1987) Nitrate reductase activity in phytoplankton from the Oslofjord, Norway. J Plankton Res 9:739-748

Kristiansen S, Paasche E (1989) An improved method for determining relative ${ }^{15} \mathrm{~N}$ abundance in ammonium regeneration studies by direct diffusion. Mar Ecol Prog Ser 54: 203-207

Kristiansen S, Farbrot T, Naustvoll LJ (2000) Production of biogenic silica by spring diatoms. Limnol Oceanogr 45: $472-478$

Kudo I, Yoshimura T, Yanada M, Matsunaga K (2000) Exhaustion of nitrate terminates a phytoplankton bloom in Funka Bay, Japan: change in $\mathrm{SiO}_{4}: \mathrm{NO}_{3}$ consumption rate during the bloom. Mar Ecol Prog Ser 193:45-51

Kuosa H, Autio R, Kuuppo P, Setälä O, Tanskanen S (1997) Nitrogen, silicon and zooplankton controlling the Baltic spring bloom: an experimental study. Estuar Coast Shelf Sci 45:813-821 
Lange CB, Hasle GR, Syvertsen EE (1992) Seasonal cycle of diatoms in the Skagerrak, North Atlantic, with emphasis on the period 1980-1990. Sarsia 77:173-187

Lännergren C, Skjoldal HR (1976) The spring phytoplankton bloom in Lindåspollene, a land-locked Norwegian fjord. Autotrophic and heterotrophic activities in relation to nutrients. In: Persoone G, Jaspers E (eds) Proceedings of the 10th European Symposium on Marine Biology, Vol. 2. Universa Press, Wetteren, $\mathrm{p}$ 363-391

Levasseur M, Therriault JC, Legendre L (1984) Hierarchical control of phytoplankton succession by physical factors. Mar Ecol Prog Ser 19:211-222

Lignell R, Kaitala S, Kuosa H (1992) Factors controlling phytoand bacterioplankton in late spring on a salinity gradient in the northern Baltic. Mar Ecol Prog Ser 84:121-131

Malone TC, Conley DJ, Fisher TR, Glibert PM, Harding LW, Sellner KG (1996) Scales of nutrient-limited phytoplankton productivity in Chesapeake Bay. Estuaries 19: 371-385

McCarthy JJ, Goldman JC (1979) Nitrogenous nutrition of marine phytoplankton in nutrient-depleted waters. Science 203:670-672

Officer CB, Ryther JH (1980) The possible importance of silicon in marine eutrophication. Mar Ecol Prog Ser 3:83-91

Olesen M (1993) The fate of an early diatom spring bloom in the Kattegat. Ophelia 37:51-66

Paasche E (1980) Silicon content of five marine plankton diatom species measured with a rapid filter method. Limnol Oceanogr 25:474-480

Paasche E, Erga SR (1988) Phosphorus and nitrogen limitation of phytoplankton in the inner Oslofjord (Norway). Sarsia 73:229-243

Paasche E, Østergren I (1980) The annual cycle of plankton diatom growth and silica production in the inner Oslofjord. Limnol Oceanogr 25:481-494

Pratt DM (1965) The winter-spring diatom flowering in Narragansett Bay. Limnol Oceanogr 10:173-184

Sahlsten E, Sörensson F, Petterson K (1988) Planktonic nitrogen uptake in the south-eastern Kattegat. J Exp Mar Biol Ecol 121:227-246

Editorial responsibility: Otto Kinne (Editor), Oldendorf/Luhe, Germany
Skjoldal HR, Wassmann P (1986) Sedimentation of particulate organic matter and silicium during spring and summer in Lindåspollene, western Norway. Mar Ecol Prog Ser 30: $49-63$

Smayda TJ (1959) The seasonal incoming radiation in Norwegian and Arctic waters, and indirect methods of measurement. J Cons Int Explor Mer 24:215-220

Smayda TJ (1980) Phytoplankton species succession. In: Morris I (ed) The physiological ecology of phytoplankton. Blackwell, Oxford, p 493-570

Smetacek V (1980) Annual cycle of sedimentation in relation to plankton ecology in western Kiel Bight. Ophelia (Suppl) 1:65-76

Smetacek VS (1985) Role of sinking in diatom life-history cycles: ecological, evolutionary and geological significance. Mar Biol 84:239-251

Solórzano L (1969) Determination of ammonia in natural waters by the phenolhypochlorite method. Limnol Oceanogr 14:799-801

Strathmann RR (1967) Estimating the organic carbon content of phytoplankton from cell volume or plasma volume. Limnol Oceanogr 12:411-418

Strickland JDH, Parsons TR (1972) A practical handbook of seawater analysis, 2nd edn. Bull Fish Res Board Can 167: $1-310$

Throndsen J (1976) Occurrence and productivity of small marine flagellates. Norw J Bot 23:269-293

Throndsen J (1979) The significance of ultraplankton in marine primary production. Acta Bot Fenn 10:53-56

Tiselius P, Kuylenstierna M (1996) Growth and decline of a diatom spring bloom: phytoplankton species composition, formation of marine snow and the role of heterotrophic dinoflagellates. J Plankton Res 18:133-155

Ulshagen T, Eid J, Mathiesen E (1995) Norsk almanakk 1996. Almanakkforlaget, Oslo (in Norwegian)

Valiela I (1995) Marine ecological processes, 2nd edn. Springer-Verlag, New York

Wassmann P (1991) Dynamics of primary production and sedimentation in shallow fjords and polls of western Norway. Oceanogr Mar Biol Annu Rev 29:87-154

Submitted: January 20, 1998; Accepted: January 3, 2001 Proofs received from author(s): August 21, 2001 